\title{
STOCK-SCION INTERACTIONS ON GROWTH AND RUBBER YIELD OF Hevea brasiliensis
}

\author{
Átila Bento Beleti Cardinal ${ }^{1}$; Paulo de Souza Gonçalves ${ }^{1 *}$; Antônio Lúcio Mello Martins² \\ ${ }_{2}^{1}$ APTA/IAC/Programa Seringueira, Av. Barão de Itapura, 1481, C.P. 28 - 13001-970 - Campinas, SP - Brasil. \\ ${ }^{2}$ APTA Pólo Regional Centro Norte, Rod. Washington Luiz, km 372, C.P. 24 - 15830-000 - Pindorama, SP - \\ Brasil. \\ *Corresponding author <paulog@iac.sp.gov.br>
}

\begin{abstract}
Rubber tree cultivation [Hevea brasiliensis (Willd. ex Adr. de Juss.) Muell.-Arg.] uses mostly the budding propagation method, however the expected stand uniformity due to the use of vegetative propagation is theoretical, since high variation for yield and vigor is caused by rootstock influence. The objective of this study was to assess several combinations between clonal rootstocks and clone scions through diallel analysis, aiming at high productivity and vigor. Data consisted of five years of dry rubber yield and girth at panel opening from an experiment using a split-plot design with four replications, conducted at Pindorama, SP, Brazil, considering six rootstocks (GT 1, IAN 873, PB 235, RRIM 600, RRIM 701 and unselected seedlings) and six scions (GT 1, IAN 873, PB 235, PR 107, RRIM 600 and RRIM 701). A $6 \times 6$ partial diallel analysis summing up 36 combinations was undertaken, and general compatibility for each group of materials (rootstocks and scions) and specific compatibility among all combinations were estimated. The results have shown that PB 235 and IAN 873 rootstocks provided high yields and general compatibility values (7.9348 and 2.7647, respectively). The use of unselected seedlings as rootstocks is not recommended because they presented very low compatibility values for dry rubber yield. Towards growth vigor, the tested rootstocks have shown similar performance. Key words: compatibility, diallel analysis, girth, grafting, rubber tree
\end{abstract}

\section{INTERAÇÃO PORTA-ENXERTO X ENXERTO SOBRE VIGOR E PRODUÇÃO DE BORRACHA DE Hevea brasiliensis}

\begin{abstract}
RESUMO: Na cultura da seringueira [Hevea brasiliensis (Willd. ex Adr. de Juss.) Muell.-Arg.], o método de propagação mais usado é a enxertia, mas a uniformidade esperada usando propagação vegetativa é teórica, uma vez que altas variações para produção e vigor são causados pela influência do porta-enxerto. O objetivo do presente trabalho foi avaliar várias combinações entre porta-enxertos clonais e enxertos (clones) através de análise dialélica, visando-se alta produção e vigor. Os resultados constaram de cinco anos de produção de borracha seca e perímetro de caule na abertura do painel de um experimento em parcelas subdivididas com quatro repetições, conduzido em Pindorama, SP, Brasil, considerando-se seis porta-enxertos (GT 1, IAN 873, PB 235, RRIM 600, RRIM 701 e sementes nãoselecionadas - UnS) e seis enxertos (GT 1, IAN 873, PB 235, PR 107, RRIM 600 e RRIM 701). Foi realizada a análise do dialelo parcial $6 \times 6$, somando 36 combinações, e Compatibilidade Geral (GC) para cada grupo de materiais (porta-enxertos e enxertos) e Compatibilidade Específica (SC) dentre todas as combinações foram estimadas. Os resultados mostararam que os porta-enxertos têm forte efeito sobre a produção de borracha seca, e levaram à recomendação do PB 235 e do IAN 873 como escolhas seguras de porta-enxertos para as condições do Planalto Paulista, sendo que proporcionaram altas produções e altos valores de Compatibilidade Geral (7.9348 e 2.7647, respectivamente). O uso de sementes não-selecionadas $(\mathrm{UnS})$ como porta-enxertos não é recomendado, pois esse material apresentou valores muito baixos de compatibilidade em relação à produção de borracha seca. Em relação ao vigor de crescimento, os porta-enxertos testados mostraram desempenho semelhante. Palavras-chave: compatibilidade, análise dialélica, perímetro, enxertia, seringueira
\end{abstract}

\section{INTRODUCTION}

Propagation of rubber tree [Hevea brasiliensis (Willd. ex Adr. de Juss.) Muell.-Arg] is carried out using seeds or vegetative parts. During the early years of the rubber crops, propagation was made trough seeds only. After 1917, vegetative propagation by budding became very common. At the present, seeds are utilized mainly for the production of rootstocks.

A number of experiments compared illegitimate seedlings of different clones as rootstocks (Schweiser, 1938; Schmöle, 1941; Paardekooper, 1954; Buttery, 
1961; Combe \& Gerner, 1977; Ng at al., 1981; Gonçalves \& Martins, 2002), and some of these trials showed strong rootstock effect on scion yield. Differences between the rubber yield of a clone scion budded onto different rootstocks were reported by Schmöle (1941) up to $20 \%$, and by Paardekooper (1954) up to $18 \%$. On the other hand, five experiments including a number of scions and illegitimate seedling families as rootstocks were carried out between 1931 and 1941 in Malaysia; in two of them, significant rootstock influence on girth and yield was detected. Later on, $\mathrm{Ng}$ et al. (1981) showed that rootstocks could significantly influence the growth and yield of the scions, although without rootstock $\times$ scion interaction. Ahmad (1999) demonstrated the effect of rootstock on growth and water use efficiency of different rubber tree clones, whereas Sobhana et al. (2001) studied the physiological and biochemical aspects of stock/scion interaction in Hevea. Interstocks can also affect the growth and physiology of grafted rubber trees, as reported by Leong \& Yoon (1978).

Selection of good rootstocks is therefore important to obtain high yield of the scion. Monoclonal seedlings from widely adopted clones in the São Paulo State, Brazil are being used in this study, and previous results (Gonçalves et al. 1994; Martins et al. 2000; Ramos 2001; Gonçalves \& Martins 2002) have observed and explained the rootstock effect on vigor, but there is still a lack of information on the longterm yield performance of the rootstock/scion combinations.

This study is expected to increment the understanding on rootstock combining ability for rubber yield and growth vigor, and on the process of choosing better rootstocks among the available rootstock clone material for future exploitation.

\section{MATERIAL AND METHODS}

Six rubber tree clones (viz. GT 1, IAN 873, PB 235, PR 107, RRIM 600 and RRIM 701) and six rootstocks (viz. GT 1, IAN 873, PB 235, RRIM 600, RRIM 701 and unselected seedlings - UnS) were combined to give a $6 \times 6$ partial diallel type of budding design. The places of origin and parentage of the clones are shown in Table 1. The illegitimate seeds for the rootstocks were collected in the border of monoclonal blocks sizing at least $2.0 \mathrm{ha}$; the scions were collected from the budwood stock nursery in Pindorama $\left(21^{\circ} 13^{\prime} \mathrm{S}, 48^{\circ} 56^{\prime} \mathrm{W}, 560 \mathrm{~m}\right)$. The seeds were germinated in pre-nursery and transferred to polybags. One year later, the rootstocks (seedlings) raised in the polybags were bugrafted with the clonal materials (scions).
Table 1 - Rubber tree clones, parentage and places of origin.

\begin{tabular}{lcc}
\hline Clone & Parentage $^{(\mathrm{a})}$ & Origin \\
\hline GT 1 & Primary clone & Indonesia \\
IAN 873 & PB $86 \times$ FA 1717 & Brazil \\
PB 235 & PB 5/51 $\times$ PB S/78 & Malaysia \\
PR 107 & Primary clone & Indonesia \\
RRIM 600 & Tjir $1 \times$ PB 86 & Malaysia \\
RRIM 701 & $44 / 553 \times$ RRIM 501 & Malaysia \\
\hline
\end{tabular}

(a)GT: Gondang Tapen; RRIM: Rubber Research Institute of Malaysia; IAN: Instituto Agronômico do Norte; PB: Prang Besar; Tjir: Tjirandji; FA: Ford Acre.

This design of 36 rootstock/scion combinations was tested in field, following a randomized splitplot design with four replications. Each of the six treatments (rootstocks) and six sub-treatments (scions) were built up with 36 and six trees, respectively, spaced $7 \times 3 \mathrm{~m}$. The trial was set up on a deep, abrupt, welldrained Paleudox. The predominant climate is Aw, according to the Köppen classification, having wet summer and dry winter periods. Mean annual temperature is of about $22.2^{\circ} \mathrm{C}$, varying monthly from $16.6^{\circ} \mathrm{C}$ to $28.9^{\circ} \mathrm{C}$ and the mean annual rainfall is $1.390 \mathrm{~mm}$. The period from October to April usually has favorable climatic conditions for growth and production, and low precipitation and temperatures occur from May to September.

The girth of each tree was measured annually starting from the date of planting. Pre-tapping girth assessments were taken at a height of $120 \mathrm{~cm}$ above the highest point of bud union. Nine years later, all the trees that reached a girth of $45 \mathrm{~cm}$ or more had the panel opened for tapping at a height of $120 \mathrm{~cm}$ above the bud union. Attempts were made in order to record girth at panel opening measurements and five annual yields.

The trees were tapped on a $1 / 2 \mathrm{~S} d / 45 \mathrm{~d} / 7.11$ $\mathrm{m} / \mathrm{y}$ ET $2.5 \%$ Ga $8 / \mathrm{y}$ system (half spiral cut, four times per day, with five tapping days in the week, during 11 months per year, $2.5 \%$ etephon stimulation on the tapping groove, eight applications per year). After tapping, the latex was collected in plastic cups provided for each recording tree. Once the latex flow stopped, it was coagulated in the cup itself by adding $2.0 \%$ of acetic acid solution and stirring it well. The coagulated rubber of each cup was then made into a "biscuit", which was tied to each tree for about 30 days for drying. Then, they were weighed and the dry rubber content for each tree was recorded.

General and specific combining ability comparisons between the rootstock and the scion combinations were made by evaluating the magnitude of the 
general and specific combining ability effects obtained from the diallel analysis. The combinatory analysis method was applied to the data of the study, which included the analysis of variance for the combinations, the general combining ability for each group of materials (both rootstocks and scions), the specific combining ability, and the estimation of their effects. The following statistical model was used:

$Y_{i j}=\mu+g_{j}+g_{j}^{\prime}+S_{i j}+\bar{\varepsilon}_{i j}$

where: $Y_{i j}=$ mean value of the $i^{\text {th }}$ rootstock (group 1) combined with the $j^{\text {th }}$ scion (group 2); $\mu$ = general mean; $g_{i}=$ value of the general combining ability of the $i^{\text {th }}$ rootstock; $g_{j}^{\prime}=$ value of the general combining ability of the $j^{\text {th }}$ scion; $s_{i j}=$ value of the specific combining ability; $\bar{\varepsilon}_{i j}=$ mean experimental error. The statistical computer program "Genes" Windows version (Cruz, 2001) was used for this procedure.

The parameters obtained by the above described methodology were renamed: the General Combining Ability (CGA) and Specific Combining Ability (SCA) are expressed as General Compatibility (GC) and Specific Compatibility (SC), respectively. These terms are more adequate to the relation that exists between rootstocks and scions, once they do not belong to the breeding design, but are combinations between materials which are physiologically compatible in higher or lower degrees.

\section{RESULTS AND DISCUSSION}

Means for the rootstock and scion combinations for dry rubber yield over five years are in Table 2 . The PB 235 rootstock presented a general mean of $53.25 \mathrm{~g}$ tree $^{-1}$ tapping $^{-1}, 17.5 \%$ greater than the general mean of the experiment, similar only to the performance of the IAN 873 rootstock and superior in comparison to other three rootstocks. Four of the tested rootstocks had a similar behaviour according to the LSD mean comparison test, viz. IAN 873, RRIM 600, GT 1 e RRIM 701. The worst performance was obtained for UnS.

Relative to the scions, RRIM 600 and PR 107 were superior, followed by PB 235 and GT 1, RRIM 701 and IAN 873 had weak performances, showing yields $26 \%$ and $30 \%$ smaller than the experiment general mean, respectively. For the GT 1 scion, the rootstock that provided the highest yield was PB 235 (41\% superior than that of UnS). The IAN 873 clone presented lower mean yield, but the best rootstock was RRIM 600, which reached yields $86 \%$ greater than UnS.

When analysing the performance of rootstocks for the PB 235 clone, the best rootstock was the one obtained from seeds of the clone itself, followed by GT 1, since both of them had approximately $60 \%$ greater yields than UnS. Similar situation happens when rootstocks for the PR 107 scion are compared.

PB 235 as a rootstock lead also to high yields for the RRIM 600 scion, almost $74 \%$ superior when compared to the expected value of UnS. For the UnS (rootstock) $\times$ RRIM 600 (scion) combination, Pereira et al. (1999) have found a first year yield of $21.20 \mathrm{~g}$ tree $^{-1}$ tapping $^{-1}$, in Goiânia, State of Goiás, Brazil, due to less favourable environmental growing conditions than those prevailing here. The scion RRIM 701 had the best yields when budded over the RRIM 600 rootstock, but all other tested rootstocks provided at least $40 \%$ greater yields than UnS for this clone.

Means for girth at panel opening for all the rootstock/scion combinations are in Table 3. For the GT 1 clone, the highest girth value was attained with the use of UnS rootstocks, whereas IAN 873 and PB 235 rootstocks had the smallest girth. Analysing the IAN 873 clone, the largest vigor was reached by using RRIM 701 rootstocks, and on the other hand, RRIM 600 rootstocks provided the largest vigor loss. Referring to the PB 235 clone, the highest vigor was

Table 2 - Means for rubber yield averaged over five years $\left(\mathrm{g} \mathrm{tree}^{-1}\right.$ tapping $\left.^{-1}\right)$ for combinations of six rootstocks and six scions of rubber tree (Hevea), and respective general means.

\begin{tabular}{lccccccc}
\hline \multirow{2}{*}{ Rootstocks } & \multicolumn{9}{c}{ Scions } \\
\cline { 2 - 8 } & GT 1 & IAN 873 & PB 235 & PR 107 & RRIM 600 & RRIM 701 General means \\
\hline GT 1 & 38.50 & 35.72 & 56.30 & 60.90 & 57.21 & 35.17 & $47.30 \mathrm{~b}$ \\
IAN 873 & 42.93 & 29.74 & 50.56 & 63.60 & 66.02 & 35.64 & $48.08 \mathrm{ab}$ \\
PB 235 & 44.26 & 35.30 & 58.56 & 69.65 & 76.73 & 35.01 & $53.25 \mathrm{a}$ \\
RRIM 600 & 42.12 & 38.60 & 49.36 & 59.90 & 56.71 & 37.28 & $47.32 \mathrm{~b}$ \\
RRIM 701 & 38.33 & 29.84 & 45.02 & 56.30 & 53.69 & 34.17 & $42.89 \mathrm{~b}$ \\
\hline UnS & 31.31 & 20.73 & 36.41 & 41.05 & 44.15 & 24.66 & $33.05 \mathrm{c}$ \\
\hline General means & $39.57 \mathrm{c}$ & $31.66 \mathrm{~d}$ & $49.37 \mathrm{~b}$ & $58.57 \mathrm{a}$ & $59.08 \mathrm{a}$ & $33.66 \mathrm{~d}$ &
\end{tabular}

Means followed by the same letter do not differ at Fischer's LSD 5\%. 
Table 3 - Means for girth (in $\mathrm{cm}$ ) at panel opening for combinations of six rootstocks and six scions of rubber tree (Hevea), and respective general means.

\begin{tabular}{lccccccc}
\hline \multirow{2}{*}{ Rootstocks } & \multicolumn{9}{c}{ Scions } \\
\cline { 2 - 7 } & GT 1 & IAN 873 & PB 235 & PR 107 & RRIM 600 & RRIM 701 General means \\
\hline GT 1 & 51.33 & 48.03 & 49.93 & 51.46 & 51.47 & 51.23 & $50.57 \mathrm{a}$ \\
IAN 873 & 49.16 & 48.96 & 54.07 & 46.51 & 51.24 & 48.89 & $49.81 \mathrm{a}$ \\
PB 235 & 48.96 & 52.10 & 53.58 & 52.07 & 49.70 & 44.36 & $50.13 \mathrm{a}$ \\
RRIM 600 & 51.53 & 43.80 & 51.78 & 50.41 & 53.58 & 47.30 & $49.73 \mathrm{a}$ \\
RRIM 701 & 52.12 & 53.56 & 52.68 & 48.95 & 51.93 & 46.46 & $50.95 \mathrm{a}$ \\
UnS & 52.15 & 52.32 & 50.47 & 53.73 & 46.44 & 45.64 & $50.12 \mathrm{a}$ \\
\hline General means & $50.88 \mathrm{ab}$ & $49.80 \mathrm{~b}$ & $52.09 \mathrm{a}$ & $50.52 \mathrm{ab}$ & $50.72 \mathrm{ab}$ & $47.32 \mathrm{c}$ & \\
\hline
\end{tabular}

Means followed by the same letter do not differ at Fischer's LSD 5\%.

Table 4 - Mean squares of the analysis of variance for Combinations, General Compatibility (GC) for both rootstocks and scions and Specific Compatibility (SC), relative to rubber yield averaged over five years $\left(\mathrm{g}\right.$ tree $^{-1}$ tapping $\left.^{-1}\right)$ and girth at panel opening (in $\mathrm{cm}$ ) of six rootstocks and six scions of rubber tree (Hevea) combinations.

\begin{tabular}{lccc}
\hline Source of variation & D.F. & Rubber yield & Girth \\
\hline Combinations & 35 & $714.2156 * *$ & $25.2987^{*}$ \\
GC rootstocks & 5 & $1127.5013 * *$ & $5.3276^{\text {ns }}$ \\
GC scions & 5 & $3538.5043 * *$ & $43.9541^{* *}$ \\
SC & 25 & $66.7087 \mathrm{~ns}$ & $25.5422^{*}$ \\
Error & 75 & 81.8965 & 13.3756 \\
General means & & 45.32 & 50.20 \\
\hline CV $(\%)$ & & 25.78 & 6.20 \\
\hline
\end{tabular}

ns $=$ not significant $*$ and $* *$ significant at $P<0.05$ and $P<0.01$, respectively.

attained with the IAN 873 rootstock, representing the largest girth of the experiment. Concerning rootstocks for the PR 107 scion, UnS presented the best performance, since all other rootstocks provided smaller girth than this material, but when RRIM 600 growth performance is evaluated, seeds and rooststocks obtained from the clone itself had a $15 \%$ greater vigor than UnS. For the RRIM 701 clone, GT 1 rootstocks gave good girth values, and on the other hand, PB 235 rootstocks reduced the vigor of the scion.

Both GSs were significant for rubber yield, but SC was not a significant parameter (Table 4). Similar results were found by Gonçalves \& Martins (2002) when analysing the first year yield of the same trial, but a Griffing diallel was used at that time, which did not allow the splitting of GC. When the girth at panel oppening is taken into account, it is noted that only GC for the scion group and SC were significant, demonstrating that rootstocks' GC values are not representative. This agrees with the data shown in Table 3 , and that therefore cannot be used to determine differences in the general means obtained by each rootstock. Coefficients of variation $(\mathrm{CV} \%)$ were high for rubber yield and very low for girth, but both were inside the limits found in other studies (Ramos et al., 2001; Premakumari et al., 2002).

GC values for both groups of tested materials and the SC for each combination, relative to rubber yield (Table 5) indicate that the magnitude of GC for the PB 235 rootstock shows that this material has great capacity of providing any scion high yields, since its value was more than twice the second, for IAN 873. This situation totally agrees with the data contained in Table 2, where the PB 235 rootstock superiority was clearly defined. Unselected seedlings (UnS) have shown highly negative GC value $\left(g_{i}=-12.2653\right)$, leading to the conclusion that this type of rootstock generally decreases the productive potential of the scions; the same happens with the use of the RRIM 701 rootstock, but in a smaller magnitude. The rootstocks obtained from IAN 873, RRIM 600 and GT 1 seeds have shown similar magnitudes of GC, with a mean value of $g_{i}=2.2521$, among the three of them.

Gonçalves \& Martins (2002) have found that for the first yielding year the RRIM 600 had the highest GC among five of the materials tested in this study, but PB 235 appeared in second place for the same parameter. The superiority of PB 235 was only confirmed after five years of rubber yield recording. These results indicate that both materials are good rootstocks to be used aiming at high yields.

Relative to the GC for scions, the superiority of the RRIM 600 and PR 107 clones was noted, agreeing with the general means for the same materials (Table 2). The IAN 873 as a scion had the lowest GC among all tested clones, as it presented also the lowest yields no matter the rootstock used; this also con- 
Table 5 - General Compatibility values for rootstocks and scions and Specific Compatibility values for each combination, relative to rubber yield averaged over five years $\left(\mathrm{g} \mathrm{tree}^{-1}\right.$ tapping $\left.^{-1}\right)$ of six rootstocks and six scions of rubber tree (Hevea) combinations.

\begin{tabular}{lrrrrrrr}
\hline \multirow{2}{*}{ Rootstocks } & \multicolumn{9}{c}{ Scions } \\
\cline { 2 - 7 } & GT 1 & IAN 873 & PB 235 & PR 107 & RRIM 600 & \multicolumn{2}{c}{ RRIM 701 Rootstock GC } \\
\hline GT 1 & -3.0578 & 0.5865 & -3.2517 & 0.5344 & 1.1842 & 4.0045 & 1.9824 \\
IAN 873 & 2.0824 & -4.6782 & -4.2894 & 4.9312 & 0.6124 & 1.3417 & 2.7647 \\
PB 235 & 4.9485 & -1.5682 & 1.2559 & -2.0223 & -1.9218 & -0.6920 & 7.9348 \\
RRIM 600 & 0.3530 & 2.2668 & 3.1495 & -0.6754 & 0.1563 & -5.2501 & 2.0092 \\
RRIM 701 & -3.8591 & 4.1710 & 9.7119 & -4.3796 & -2.9732 & -2.6709 & -2.4259 \\
UnS & -0.4669 & -0.7779 & -6.5761 & 1.6119 & 2.9422 & 3.2668 & -12.2653 \\
\hline Scion GC & -5.7428 & -13.6623 & 4.0508 & 13.2505 & 13.7672 & -11.6633 & \\
\hline
\end{tabular}

Table 6 - General Compatibility values for rootstocks and scions and Specific Compatibility values for each combination, relative to girth at panel opening (in $\mathrm{cm}$ ) of six rootstocks and six scions of rubber tree (Hevea) combinations.

\begin{tabular}{lccccccc}
\hline \multirow{2}{*}{ Rootstocks } & \multicolumn{9}{c}{ Scions } \\
\cline { 2 - 7 } & GT 1 & IAN 873 & PB 235 & PR 107 & RRIM 600 & \multicolumn{2}{c}{ RRIM 701 Rootstock GC } \\
\hline GT 1 & 0.1014 & -1.2999 & -1.8250 & 1.1443 & 0.5156 & 1.3647 & 0.3553 \\
IAN 873 & -2.1224 & -0.4212 & 2.3980 & -5.5090 & 3.0343 & 2.6209 & -0.4134 \\
PB 235 & -2.5120 & 2.4017 & 1.5809 & 0.1809 & -0.1353 & -1.5162 & -0.0926 \\
RRIM 600 & 0.5818 & -3.5995 & 1.6397 & 0.3797 & -2.3015 & 3.3001 & -0.4851 \\
RRIM 701 & 0.3901 & 0.9263 & -0.9320 & 3.3355 & 0.4718 & -4.1916 & 0.7312 \\
UnS & 3.5614 & 1.9926 & -2.8600 & 0.4693 & -1.5844 & -1.5778 & -0.0955 \\
\hline Scion GC & 0.6558 & -0.4230 & 1.8665 & 0.3003 & 0.5045 & -2.9042 &
\end{tabular}

firms that GC is a good comparison parameter for both groups under the tested conditions.

The values found for SC for yield confirmed that it was a non-significant parameter through the analysis of variance. For an example, the highest value of SC among all the combinations was obtained by the RRIM 701 (rootstock) $\times$ PB 235 (scion), with $s_{i j}$ $=9.7119$, but in fact this combination had an yield of $52.68 \mathrm{~g} \mathrm{tree}^{-1}$ tapping $^{-1}$ (Table 2), which was above the experiment general mean, but represented less than $70 \%$ of the highest yield, achieved by the PB 235 (rootstock) x RRIM 600 (scion) combination, that reached a very low SC value $\left(s_{i j}=-1.9218\right)$. These results are in accordance with Webster (1989), who stated that the scion has the major influence on yield, but the rootstock can also have a marked influence. Furthermore a scion can affect the growth of the rootstock - a vigorous scion increasing the growth of a weaker rootstock for example. Mechanisms related to the genetic yield capacity of the rootstock are evidently involved in its influence on scion yield (Paardekooper, 1954), as it was observed that the effect of the rootstock on rubber yield, was greater when the tapping cut was closer to the bud union, which seems likely to be due to the fact that latex is withdrawn from the stem to the roots of the seedling stock.

The values for GC and SC relative to girth growth are Table 6 . The rootstocks presented very similar values of GC, as it was expected since the performed mean comparison test indicated that there was no difference in rootstock effect over the analyzed variable. Even though, the PR 107 and GT 1 rootstocks had slightly higher values than the other tested materials.

In relation to $\mathrm{GC}$ for scions, differences are clear. Scions from PB 235 had the highest value $\left(g^{\prime}{ }_{j}\right.$ $=1.8665)$, confirming the highest girth growth mean shown in Table 3, and states that this scion can grow reasonably well independently of the rootstock. But when SC values for girth (significant by the analysis of variance) are taken into account, each combination has its particular behaviour. For the GT 1 scion, for instance, the highest value of SC was provided by the use of UnS $\left(s_{i j}=3.5614\right)$, but this same UnS rootstock had a strong depressive effect over the PB 235 scion vigor (showing a $s_{i j}$ value of -2.8600). A similar situation shows up when comparing the SC for other two combinations: the RRIM 701 rootstock increased the growth potential of the PR 107 clone $\left(s_{i j}=3.3355\right)$, 
but on the contrary, decreased the girth of the clone itself (RRIM 701 rootstock x RRIM 701 scion, with $s_{i j}$ value of -4.1916). The RRIM 600 clone when budded onto self seedling rootstocks also presented negative values of SC, but a clone can benefit from a reciprocal combination (rootstock and scion from the same clone), as it was the case of PB 235. The lowest SC found among all 36 combinations was attained by the IAN 873 rootstock $\times$ PR 107 scion, but did not agree with the lowest girth mean.

\section{CONCLUSIONS}

The tested rootstocks have strong effect on yield of the scions. PB 235 and IAN 873 rootstocks are safe choices for the conditions of the Central São Paulo State Plains since they provided high yield GC values, leading to their recommendation for the "Planalto Paulista" conditions. Unselected seedlings (UnS) have shown highly negative GC values and their use can no longer be recommended, since they decreased the productive potential of all the scions budded onto this type of rootstock. Highly significant SC allowed identifying better rootstock $\mathrm{x}$ scion combinations towards girth growth.

\section{ACKNOWLEDGEMENTS}

The authors thank FAPESP and CNPq for their financial support over years. They are also thankful to their co-workers in the Seringueira Program.

\section{REFERENCES}

AHMAD, B. Effect of rootstock on growth and water use efficiency of Hevea during water stress. Journal of Rubber Research, v.2, p.99-119, 1999.

BUTTERY, B.R. Investigations into relationship between stock and scion in budded trees of Hevea brasiliensis. Journal of the Rubber Research Institute of Malysia, v.17, p.46-76, 1961.

COMBE, J.C.; GERNER, P. Effect of the stock family on the growth and production of grafted Heveas. Journal of the Rubber Research Institute of Sri Lanka, v.54, p.83-92, 1977 .
CRUZ, C.D. Programa Genes: versão Windows, Aplicativo computacional em genética e estatística. Viçosa: UFV, 2001. $641 \mathrm{p}$.

GONÇALVES, P. de S.; MARTINS, A.L.M. Combining ability effects of clonal rootstocks and scions in rubber trees (Hevea). Crop Breeding and Applied Biotechnology, v. 2, p. 445452, 2002.

GONÇALVES, P. de S.; MARTINS, A.L.M.; BORTOLETTO, N.; ORTOLANI, A.A.; BERMOND, G. Avaliação do vigor de seis diferentes populações de porta-enxertos de seringueira. Pesquisa Agropecuária Brasileira, v.29, p.543-552, 1994.

LEONG, W.; YOON, P.K. Effect of interstock on growth analysis of Hevea. Journal of the Rubber Research Institute of Malaysia, v.26, p.99-104, 1978.

MARTINS, A.L.M.; RAMOS, N.P.; GONÇALVES, P. de S.; VAL, K.S. Influência de porta-enxertos no crescimento de clones de seringueira no Estado de São Paulo. Pesquisa Agropecuária Brasileira, v.35, p.1743-1750, 2000.

NG, A.P.; HO, C.Y.; SULTAN, M.O.; OOI, C.B.; LEW, H.L.; YOON, P.K. Influence of six rootstocks on growth and yield of six scion clones of Hevea brasiliensis. In: RRIM PLANTERS'S CONFERENCE, London, 1981. Proceedings. London, 1981. p.134-151.

PAARDEKOOPER, E.C. Resultaten van twee onderstamproeven bij Hevea. De Bergecultures, v.27, p.551-553, 1954.

PEREIRA, A.; VENTURIN, N.; PEREIRA, E.B.C.; FIALHO, J. de F.; JUNQUEIRA, N.T.V.; GONÇALVES, P. de S. Avaliação preliminar do desempenho de clones de seringueira (Hevea spp.) na região de Goiânia. Cerne, v.5, p.24-35, 1999.

PREMAKUMARI, D.; RAMESH, B.N.; SOMAN, T.A.; JOHN, A.; NAZEER, M.A. Genetic influence for intraclonal variations and associations of juvenile yield and girth in thirteen Hevea clones in Kanyakumari region of south India. Indian Journal of Natural Rubber Research, v.15, p.28-32, 2002.

RAMOS, N.P.; GONÇALVES, P. de S.; MARTINS, A.L.M.; GODOY JR., G. Avaliação genética em diferentes combinações de enxerto e porta-enxerto de seringueira. Científica, v.29, p.103-115, 2001.

SCHMÖLE, J.F. Hevea brasiliensis and Hevea spruceana hybrids as stocks for bud-grafts. Archief voor der Rubbercultuur in Nederlandsch, v.25, p.159-167, 1941.

SCHWEISER, J. Over den wederzijdschen involued van bovenen ondertsan bij Hevea brasiliensis. De Bergecultures, v.12, p.773-775, 1938 .

SOBHANA, P.; GOPALAKRISHNAN, J.; JACOB, J.; SETHURAJ, M.R. Physiological and biochemical aspects of stock-scion interaction in Hevea brasiliensis. Indian Journal of Natural Rubber Research, v.14, p.131-136, 2001.

WEBSTER, C.C. Preparation of land for planting and replanting. In: WEBSTER, C.C. BAULKWILL, W.J. (Ed.). Rubber. New York: Longman Scientific \& Technical, 1989. p.165-194.

Received May 18, 2006

Accepted March 06, 2007 